\title{
Building Resilient Communities through Bottom up Approach: Case Study of a Rural Education Centred NGO from Nepal
}

\author{
Kanchan Pd. Kharel' ${ }^{1}$, Venkat Pulla ${ }^{2, *}$ \\ ${ }^{1}$ Kathmandu University, Kathmandu, Nepal \\ ${ }^{2}$ The School Social Sciences, University of the Sunshine Coast, Maroochydore, Qld, 4558, Australia \\ *Corresponding author:dr.venkat.pulla@gmail.com
}

\begin{abstract}
There are a number of Non-Government Organisations (NGOs) working in the third world's field of educating children in rural areas. In this paper, we review an experience of a purely children's education centered NGO that works in western Nepal, the facilitator of which received the Ramon Magsaysay award in 2007. This NGO uniquely demonstrates the variety of entrepreneurship through self-help groups that generate profits to run and support education for the children. At the conceptual level, the paper begins with the relationship between aid and development in the third world, its impact on poverty reduction; thus presenting a framework for resilience and also reviewing the development of the 'bottom up approach' favorably considered as programme strategy in this NGO. As part of this qualitative paper, the authors have also provided brief biographical details of the founder of the NGO and his mission to make his community self-reliant as resilient.
\end{abstract}

Keywords NGOs, Strengths Approach, Coping and Resilience, Regional Development, Social Work in Remote Communities, Sustainability

\section{Introduction}

The relation between Non-governmental Organisations and International Non-governmental Organisations (NGOS and INGOs) and 'rural development' has been dealt by many development scholars, academicians, activists and critics. Writers highlight the role of NGOs/INGOs as the 'Care taker' of rural development and poverty alleviation strategies. In contrast, critics of Neo-liberalist development models argue that NGOs/INGOs create 'dependency syndrome' among community people in the name of community development (Burnell, 2011). Despite such critiques, NGOs/INGOs have managed to remain in this sector and some have even excelled in terms of empowering the vulnerable people of remote and fragile topographies and locations. Since the seventies, NGOs/INGOs have been playing crucial role in changing directionality of development by making critical improvements around 'how development should flow'. The 'top-bottom' directionality, and capital intensive, has been questioned for not being effective in confronting poverty and inequality and for creating passive recipients of development (Parnwell, 2011). In contrary, NGOs are appreciated for its bottom-up or grassroots development approach, the philosophy of which according to Parnwell (2011) mainly centres around altruism, democracy, popular participation (learning together rather than the simple transfer of knowledge), empowerment, conscientization, contextual groundedness, responsiveness rather than prescriptiveness, and the promotion of self-reliance (p. 114). The bottom-up approach is believed to not only reduce the 'planning arrogance' of the experts and technocrats in developing plans and projects for poor people, but also lead participatory practices by involving people in the overall development process. In fact, post 1970s onwards, NGOs and INGOs became the key player of development as they paid more attention to bottom-up and grassroots development (Willis, 2005, p.114).

\section{Methodology}

The paper describes the efforts of a single NGO, Himanchal Education Foundation's approach in the field of education and how its visionary founder Mahabir Pun devised programmes of development in consultation with the limited social capital that was available in the village of Nangi. We identified the processes of individual development that occurred in this village and surroundings as the NGO enterprises simultaneously addressed collective economic development concerns. Our premise in this paper is that when people participate in actions that benefit themselves and the community, it is easier to scope the resilience in the community. We provide a further theoretical understanding on resilient communities within this paper in a 
separate section. A narratological framework was utilised in describing the development achieved by the community in describing the various creative ventures of economic development with a view to fund their school. This qualitative paper draws on field visits to Nangi village of Myagdi district of Nepal in the year 2013.

\section{Aid Perspectives and Micro Enterprises}

Some form of International aid either through the government; international agencies; such as United Nations Development Programme (UNDP), direct aid from INGOs to NGOs and development seem to go hand in hand in many parts of the third world. Jeffrey Sachs advocates on aid effectiveness and emphasises that the poverty trap of developing countries can only be broken with the help of Official Development Assistance, (ODA), as it contributes both to the household income and the public budget, thus affording capital formation and increasing economic growth (Sachs, 2005). Therefore, some form of aid is crucial for running development programs and cannot be ignored.

Since aid flows from one agency to the other, a major concern is around the proper channelization of its monetary components. When the concept of bottom-up development emerged, donor agencies and NGOs started discussion on the effective channelization of aid. Previously, aid was offered through a top down approach, which was largely centralised to the government. Aid used to come with requirements attached to which the government had to be the only responsible entity to answer back the achievements led by the assistance (Killick, 2011). But, with the bottom-up approach, donor agencies-especially UNDP and World Bank- became more appreciative of the demands at the grassroots and were also concerned on how the NGOs were responding to such local needs. Aid focus was turned to ensure the realisation of the sentiments of Paris Declaration on aid effectiveness which included incorporation of Ownership, Harmonization, Alignment, Results and Mutual Accountability (UNDP, 2011). The realisation of the above tenets of development was supposed to be in conjunction of the national development strategy of those developing countries where UNDP was active. Nepal was obligated to prepare its own Poverty Reduction Strategy Paper as part of its national development strategy, in line with the concept of needs at the grassroots, the information for which was also largely facilitated by NGOs and active social researchers. This resulted in the ushering in of the Micro-Enterprise Development Programme acquired by the Ministry of Industry, MOI (2010). The bottom-up development model can be best described as the community approach which takes into account the local demands and the pressing needs of the community in relation to their poverty and their performances are seen, in reference, to how they respond to the demands of the market. A Micro Enterprise Development
Program (MEDEP) is a strategic approach that focuses on two components, i.e. demands/needs of target groups and the previously considered market opportunities within the district. Within this paper, we will be reviewing some of the programmes that were set with the objective of helping low income families to increase their entrepreneurship in the study area of Nangi village of Myagdi district in the western Nepal set against the prime desire of the Village of Nangi supporting the cause of education for their children.

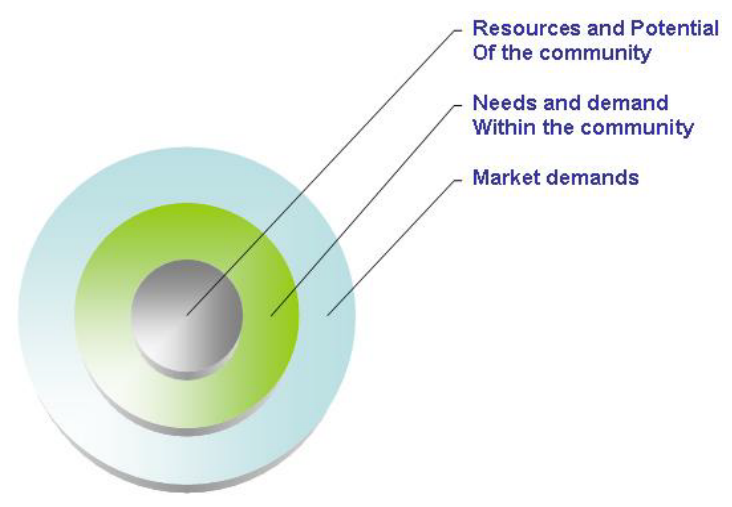

\section{Micro enterprise model}

Nangi Village- at a glance

Nangi is a small remote village in the mid hills of Myagdi district of Dhaulagiri zone in the western part of Nepal. It resides on the southern edge of the Annapurna and Dhaulagiri ranges of the Himalayas ${ }^{1}$ and has a predominantly cool climate. The village falls in Ramche Village Development Committee (VDC) which has two administrative wards: 1 and 2 with a population of around 650. One of the ethnic communities called Magar predominate this village and its surroundings. A majority of households depend on agriculture. Nangi's economy additionally is driven by remittances income from overseas where some male members of the Nangi households have been serving. Tradition has it that, at least one male in each of the Magar and Gurkha families have been serving military regiments and military establishments in India and the United Kingdom from the time of the British Rule in the Indian sub-continent. In the last two decades, this tendency has allowed younger males to also explore Malaysia, Qatar, Dubai, and other parts of Middle East in all forms of labourconstruction, industrial and domestic helps. The women folk largely remained back and took vital interest in caretaking functions within their families and the village. Women became the drivers of village's emerging and diversifying economy, agriculture in addition to their home duties and chores. The Magar and Gurkha are not patriarchal and women make decisions beyond the household. The Nangi villagers follow Hindu religion and its various festivals like

${ }^{1}$ Dhaulagiri I (8.167 m. $26.795 \mathrm{ft}$ ) and Annapurna I (8091 m. $26.545 \mathrm{ft}$ ) are the seventh and the tenth highest peaks of the world (Himanchal Education Foundation, 2004) 
Dashain and $\operatorname{Tihar}^{2}$ and also worship 'nature' as their 'Goddesses'. Reaching Nangi usually requires two to three days of travelling from Kathmandu, consisting of a seven hour bus ride or a thirty five minute plane trip to Pokhara, the second largest city in Nepal. From Pokhara, one must travel by bus or taxi for up to five hours to reach to get to Beni. And a long trek from Beni, with porter assistance that can be hired, it would take almost dawn to dusk to reach to Nangi.

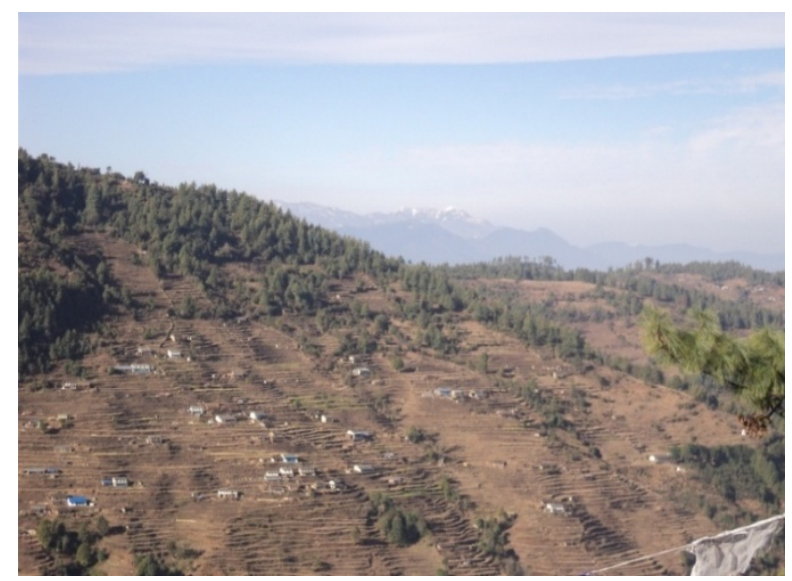

Photo showing the terrain of Ramche and Nangi surroundings

\section{Mahabir Pun}

Mahabir Pun like others from this village belongs to the Magar community whose men for generations have soldiered across the globe as Ghurkhas. Pun passed his boyhood by grazing cattle and sheep in mountain pastures and attending a village school that had no paper and pencil to use, nor a book to read from. Wanting more for his son, Pun's father moved the family to Nepal's lowlands, in Chitwan, where Pun finished his high school and became a teacher, working for twelve years to help his younger siblings through their schooling. Finally, a timely scholarship led him to a bachelor's degree at the University of Nebraska at Kearney. Then, in 1992, after more than twenty years away, Pun returned home to Nangi, determined to make things easier for the village youth than they had been for him. It is this singular dedication to give better education to Nangi children that saw him receive the Ramon Magsaysay Award. At the ceremony, Pun said:

'All of us grow up with lots of wishes. And we know for a fact that many of the wishes that we make can't be fulfilled. As a young boy my wishes were to have enough food to eat, and warm clothes and shoes to wear. I wished to have books to read, pens and papers to write on... Memories of my old days' unfulfilled wishes have become my vision of creating better educational opportunities for rural children and creating job opportunities for disadvantage people so that they can have meaningful, peaceful and better lives. The wireless network that we created in some of the mountain

\footnotetext{
${ }^{2}$ Dashain and Tihar are very popular Hindu festivals in Nepal which usually fall on October month.
}

villages for educational, medical, and local e-commerce purposes was just a small part of my vision to create better learning opportunities for the children, to provide medical assistance to villagers during emergency situations, and to bring communication tools for the villagers. We still have a long way to go to make the wireless technology truly useful for the people, and to replicate the wireless network all over the country (Pun, 2007)

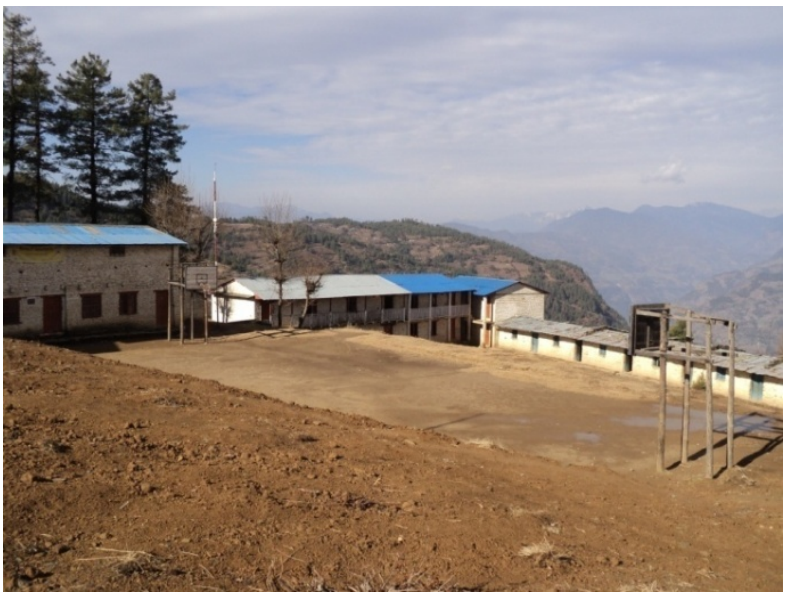

Photo: The Himanchal School that makes resilient children

\section{A Framework of Resilience}

In most simple terms "resilience" refers to the notion of an individual's predisposition to cope with stress and adversity. This coping may result in the individual "bouncing back" to a previous state of normal functioning, or would allow them from simply not showing any negative effects (Pulla, 2013). Resilience crops up in situations of adversity, risk and negative life circumstances that often lead to poor outcomes. There are many theoretical explanations and approaches that seek to address and promote resilience. Currently, research suggests that interventions and practices need to address both individual and environmental factors. It is also suggested that the approach ought to allow for a holistic multi-systemic support with due consideration to age of all people in the communities (Luthar \& Zelazo, 2003; Ungar, 2011; Walsh, 2006). While individualised and family level interventions seek to strengthen a person in resisting and persisting through adversity, the individual may also require suitable behavioral changes in combination with interventions to affect the immediate social environment (Jaffee et al., 2007). A similar view is also expressed by Walsh (2006) who supports multisystem, strengths-based understanding of family resilience and interventions that reign in the frontier of social and social cultural ecology. Most writings in resilience refer to the result of individuals being able to interact with their environments and the processes that either promote well-being or protect them against the overwhelming influence of risk factors (Zautra et al., 2010).

The association between socio-psychological and ecological resilience has been mentioned in the foregoing 
discussion. Such association has certainly widened the scope of our understanding to accept the re-emergence of personal variables and characteristics. If people are involved in activities that meet their personal needs and have stakes of their own in the community ventures, then their response to any enterprise or common cause is likely to be substantial. In this paper we present evidence to corroborate this trait and forward an argument that this is common to both individualist and collectivist societies. Theoretically, it can be said if people are well-prepared, they may be able to exploit less extreme forms of breakdown to achieve deep reform and renewal of institutions, social relations, technologies, and their entrenched habits of behavior. Successful coping appears to be liked to adaptation, whereby a person or a family successfully adopts alternatives which actually demand more competencies to overcome the stressor (Park, Peterson \& Seligman, 2004). Thus, for the purpose of this paper, resilience not only refers to adaptive capacity of people but also incorporates a dimension of sustainability as a community.

\section{Case Study of the NGO: Creativity in Micro Enterprises}

Mahabir Pun returned to his native village Nangi in Nepal after getting his Master's Degree in education from University of Nebraska, with a courageous and ambitious goal to set up a school that would serve as a model for local education as well as economic development. Nangi had a school that the community always wanted to upgrade into a high school and give more skills to the village children. This school project was assisted by a registered Himanchal Education Foundation (HEF) in Denver, USA, which was set up by Mahabir Pun and his friends overseas. HEF undertook a one dollar campaign for a while to support the staffing and development expenses of the school. The principal of the school explained that currently the school receives The Government of Nepal funding of up to sixty percent of the total cost of the teacher wages while the rest of the forty percent would have to come from the people. It is this forty percent that the people did not have for a long time. After Mahabir Pun's return to the village from his studies abroad tremendous changes have occurred. Pun put his entire attention to the school and worked with community people to help it consistently grow and sustain its running expenses. At present, Himanchal High School has been upgraded to an Intermediate level school with support from different stakeholders. We will now briefly describe major micro enterprises that the Nangi village undertook to support their lives and their school.

The NGO introduced a community trek that covers the North-East side of Myagdi district. They made small community lodges on the trekking routes by the 60 percent support of MEDEP- micro enterprise projects of the UNDP and forty percent contributed by the local residents in terms of labor and cash. These community lodge projects are run by the community and profits are passed on to the School development and staff salary. There are three Community lodges in this community trek.

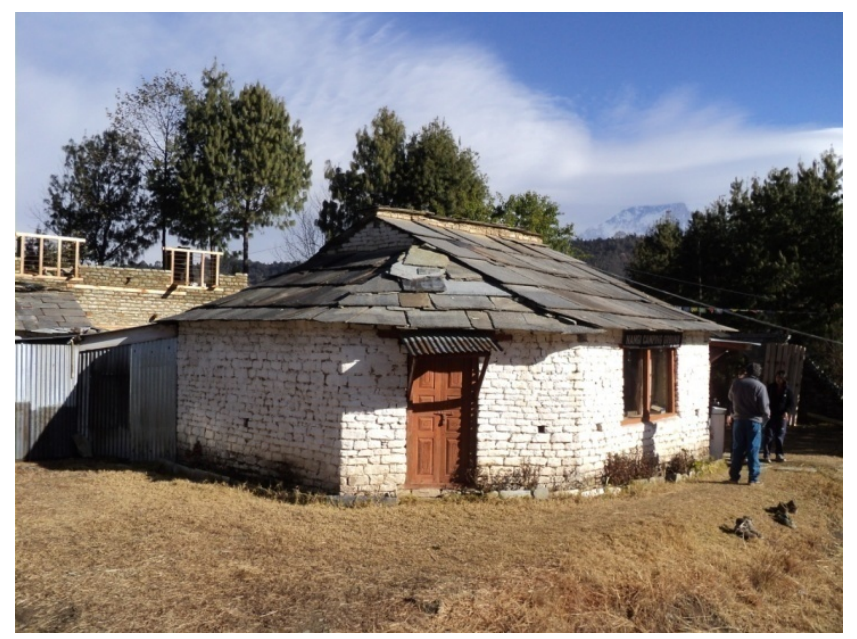

Photo showing the Community lodge for trekkers and visitors

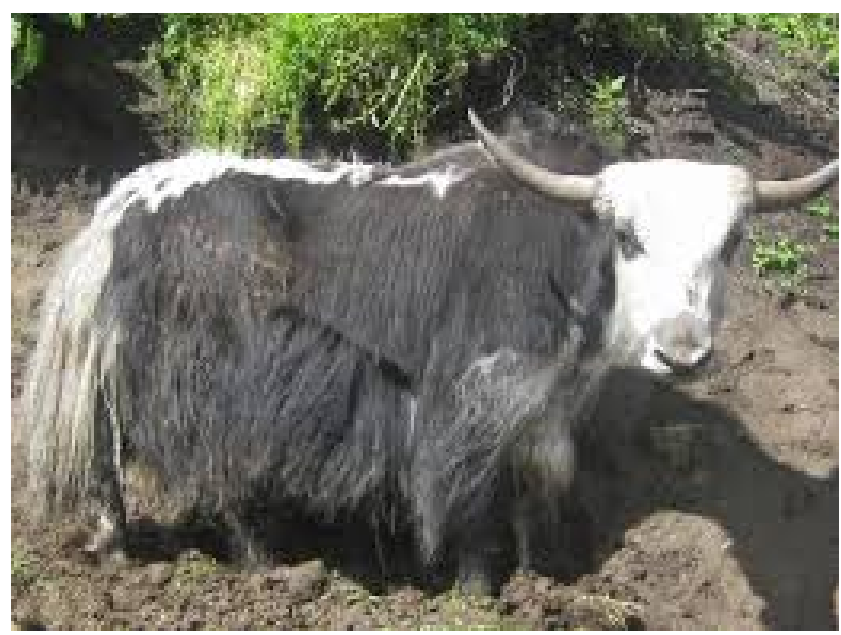

Photo from the Yak farming project

The NGO spotted the tradition of Yak farming in the area and asked the community if this was an option to pursue and could do more of it for economic development. The NGO introduced thirty yaks, in the 1997 to the Khopra region below the Annapurna and Nilgiri Himalayas. This project was a joint-venture of Himanchal High School and Paudwar High School. The program has been very successful, as there are over one hundred and forty Yaks as of now which are producing a good source of income for the schools. Almost everything from the yak is used to sustain the life of the herdsmen and their families and is used either directly or sold to provide an income. What domestic cow and buffalo are for many other South Asian communities, the Yak is for the Sherpa and the Magar communities in the Himalayan region. Yak products are sold in local markets and in Kathmandu, while some products are also sold overseas. The herdsmen and their families obtain nearly all their needs from yaks. 
The products from yaks during their lifetime are milk, hair, draught power, and dung for fuel, and after slaughter there is the meat and a number of products from the organs and non-consumable parts of the body such as the hide and the pelt. The majority of these products are used by the herdsmen and their families, but some are sold to generate income. Where yak herds are in the proximity of hill towns and villages, there is a ready market for the products, which provides cash value to yak production (Food and Agricultural Organisation, 2014). Nepal is one of the first countries in Asia to establish a cheese industry and was the only country in the world producing yak cheese until the 1980s. More than four decades have passed since the founding of Nepal's yak cheese industry (Joshi et al, 1999).

Another micro enterprise that was popularly accepted was of Rabbit rearing. Rabbit's meat is mostly used for family consumption. But more recently it is available for purchase in the local community lodges and towns in Nepal have become lucrative. Once again the profits went to the school. In addition to this, the school even undertook fish farming. This was experimented by the school despite the climatic condition of Nangi village being unfavourable for aqua culture. The small ponds in the school built in the year 2000 introduced different kinds of fish to find how well the fish could adapt and grow. Some varieties, such as silver carps, common carps and grass carps, seem to be doing well. The school has built five small fish ponds in the village. Now the pond has become a hatchery and is able to distribute fingerlings to other villagers. Hueguen Rallapali Foundation, a charity organization of the Silicon Valley in San Fransciso, one of the members, an engineer named Krishna Rallapalli and his wife Philine gifted $\$ 16,000$ to help build the four-room school. The foundation has donated thousands more for a computer and science lab and to build four fish ponds that the school uses to raise money.

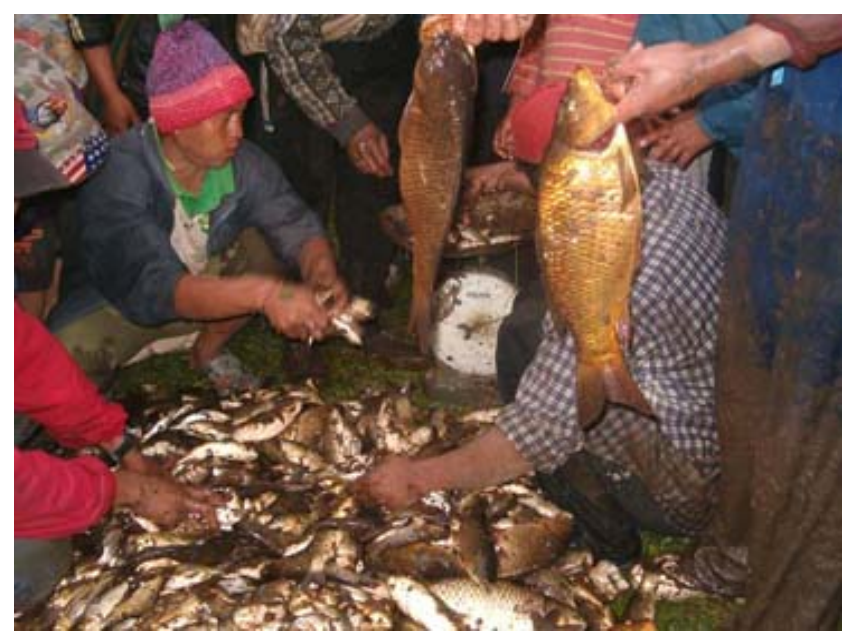

The School pond selling fish

In the year 2013 , the student-teacher ratio is 19.5 per teacher which is very effective for learning. About eighteen teachers look after around 350 students. The school continues to receive some donations for scholarship that are added to scholarship fund and administered according to pre-set criteria for scholarship purpose. Read Nepal, an NGO, has supported by providing more than 2000 books and also provided training to teachers about library management.

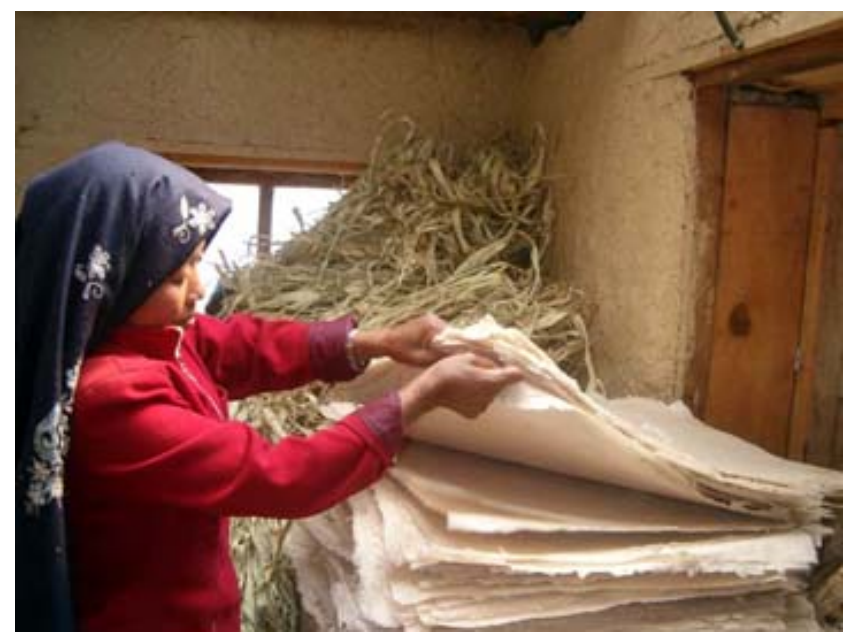

Photo showing project personnel with Handmade Paper from a local plant 'lokta'

Since 2001, the NGO has been selling raw materials for making handmade paper to a Japanese firm. The micro processed the bark of a locally grown plant called "Argeli" and sold it to the Japanese firm. This project created jobs for some villagers for about three months. In 2004, the NGO started making handmade paper by from another locally grown plant called "Lokta". Amongst other micro enterprises were activities such as another income generation activity was making honey. The ways and means to earn their livelihoods while investing in the school for educating the future generation is exemplary. The earnings from yak farming, from maintenance of community lodges, handmade paper, rabbit rearing; fish farming etc. all go to a common funding basket of the school. Profits are pooled into the NGO which channels fund into various development work of the village. However, the principal focus of the NGO is education and health. Mahabir Pun, the founder of this NGO reflects about schooling in his childhood and writes:

'Our teachers were the retired soldiers of the Second World War who had never been to schools themselves. I got pencils and paper to write with for the first time when I was in the seventh grade and text books in the eighth grade. As a school boy in my village I had never thought of going to high school. I had no ideas about high schools and colleges because nobody had told me about it.... After I graduated from the University of Nebraska in 1992, I went back to my village in the mountains. That was twenty-four years after we migrated from the village. Nobody recognized me in the village by face, nor did they know about my mission. I introduced myself to my relatives and villagers. It was before I arrived they had decided to start a high school in the village (Pun, 2014).

Earlier, Nangi had to remain illiterate due to the unavailability of a school that the community always wanted 
to build. And as their children moved from class to class, an upgrade into a high school became their goal. Most elders in the village remember how some literate youth came home during vacations belonging to families that worked in British and Indian regiments and taught the remaining children in the Village.

\section{Further Investments into Education}

The NGO built its first camping ground in Nangi village for tourists in 1996, which produced some income for the school. Following success of this first micro enterprise, they built two more camping grounds in Khopra as a joint venture project with Paudwar High School. Today this is a commercially viable tourist place that charges US ten dollars for a night's stay per person.

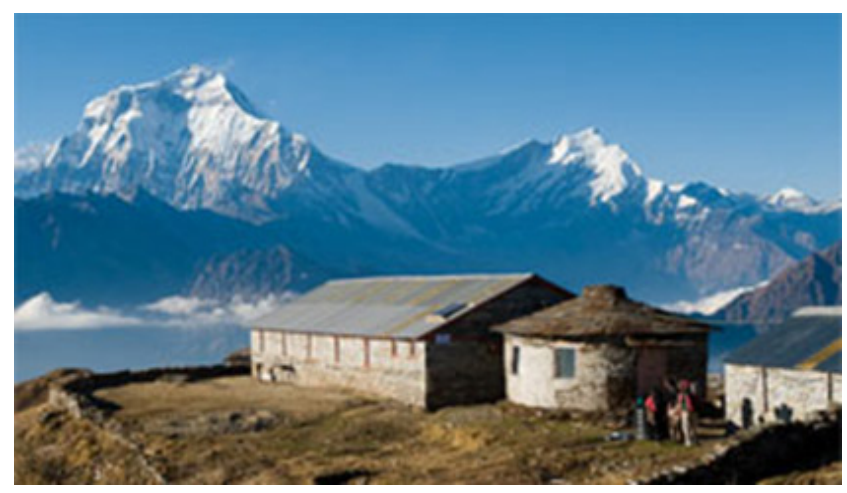

Photo shows a view of the Khopra Tourist Lodge

Mababir Pun took up the wireless project in connecting rural communities and this is hailed as milestone. He focused on information communication technology (ICT) with an aim of improving schools. This has brought a number of volunteers from far off places like New Zealand that took great interest in not only assisting in further development of ICT but in providing opportunities such as scholarships for local children that allowed them to pursue university education. Now, the students go to their computer laboratories and use internet to learn and study which is a rare situation in remote villages other than Nangi in Nepal. One of the volunteers Ankool Sathu, (2008) spent a fair amount of his time with the Wireless/VOIP (Internet Phone) project while he was living in a hut in the project area. The NGO was trying to give access to the internet to the villages, for schools to use, and also as a means of phone communication. His project involved him in a variety of testing and implementation. Installing routers/antennas and making the network within that village work well. He was also teaching English in the School for grade 12. His reflectively wrote on his experience:

'The students of this school often come from families of farmers, who have very little money and are already stretched sending their kids to school. One of the days I was with a Grade 12 boy who happened to be in my English class, and was talking with him about his plans after his final year at school. He said he had no plans; I was like "what about University?" his words were "Why have dreams about things that you cannot get?" I was sitting there and I felt humbled by my question, my mind assuming that life was always that simple. He told me about his family being farmers, and going to another city to study is well beyond their reach. Over time in my class and otherwise I noticed his enthusiasm with learning, so after consulting other teachers who agreed, I decided that funding his university studies is a good way to utilize my funds. I also had noticed a girl in my English class who was very capable with the language and much better than most students. I felt a person like her should continue with her studies. To add to that, she didn't have a father as he had passed away, and so money was a constraint for her (Sathu, 2008).

The NGO project created Hostel facility at Himanchal School for the students of neighbouring villages as well. Such hostel arrangement has become another factor for the increasing number of students in higher level studies at Himanchal School. Hostel seems to be necessary for those students who have to travel long distances every day to reach school. Hostels are making positive impact on youth and their education and have helped in decreasing the dropout rates at school before successfully completing studies and obtaining the School Leaving Certificate. There are more than 2000 books in the library of the Himanchal high school which is sufficient for the intermediate and lower level student. Students can now use books without buying. This has enabled student with greater exposure opportunities. The same library is also open for public. In addition, use of internet is able to provide positive change to students' reading habits. Lack of related books in the library is met by the provision of internet facility.

While the purpose of this paper was to describe innovative micro enterprises that were launched by the community with an impetus of purely seeing their children receive education, a related but equally important element in the paper was to review the activities by individuals and groups that promoted community resilience and ensured contributing to food security. We would briefly discuss ways by which the insecurity was mitigated by micro enterprises by the NGO. Related to food security were products such as Jam Production, Mushroom Farming, Rabbit rearing, and Livestock farming. Certainly a level of economic sufficiency in all aspects may require more work but with the engagement in various income generating activities, Nangi household shave demonstrated that they are capable to earn an income to break away from poverty. It has been pointed out by the project personnel that additional incomes have not been sufficient to pay for increasing food prices of non-local foods that are entering the patterns of changed food patterns in the Nangi villages. According to a teacher at the school:

'parents formerly used to send potatoes, local bread, fruits as part of children's lunch today they are being replaced by cooked noodles or with money for lunch to buy 
potato chips, noodles and biscuits. This gradual change in habits to consume readymade and packed food items does negatively impact on the nutritional status of children'

Likewise, livestock farming such as cows, goats, chicken, rabbit, not only provide them direct services such as milk, meat, and dried dung for fertilisers and fuel but also serve as a form of current assets that can be exchanged with food items during the need of the hour to meet food urgency or sold to purchase food. For this reason, there is a slight tendency among villagers to invest on livestock as they yield quick return. Also, there is no investment made in gold except the ones that are inherited.

We have previously made a cursory reference to the dependence on remittances from male members working overseas. Location of a recent commencement of remittance services has eliminated the need to travel several hours to receive funds remitted by family members living overseas. Additionally these remitted incomes now have the full capacity to be absorbed within the Nangi village for consumption and savings of the receiving families. This access to financial services in Nangi allows people to manage their household cash flows, start new agricultural activities and set-up small scale business.

\section{Discussions and Conclusions}

We have presented here a descriptive case study. We are convinced that the achievements of this NGO in Nangi are by no means great, but their uniqueness rests in the fact that these successes were inspired by having one single need met, namely to have a school for their children and to supplement the partial subsidy by the state. The spirit towards developing self-reliance has begun. The trekking routes and lodges across the route that are built we believe will contribute to improvement of infrastructures and supplement the village income. Certainly there are some threats to the long term economic efficacy of such hilly habitats. They are remote and therefore carry the risk of being stranded. They tend to be smaller, isolated, and also have children migrating for higher studies and non-agricultural pursuits. More and more people from vulnerable groups of frail aged men and women are stranded. In the nomenclature of development, these variables serve as policy risks and often conversations are muted. Fair and even treatment of these people from entitlements perspective through support pensions; maintenance of infrastructure assumes long term planning. When economies are vulnerable and susceptible, social capital, networks, belief systems, cultural values, and levels of cognition will affect the response capacity of communities (Klein, Huq, Denton, Downing, Richels, Robinson \& Toth, 2007). Similar to indigenous communities in other parts of the world, communities living in the Himalayan region especially those on country or traditional lands, have similarities for servicing priorities $\left(\mathrm{DCCEE}^{3}, 2007\right.$, p. 8; Hennessy, et. al., 2007). In such places repositories of

\footnotetext{
${ }^{3}$ Department of Climate Change and Energy Efficiency (DCCEE)
}

traditional knowledge and untapped resources abound that communities may be able to use education, consider adaptation options given their skills in living in sustainable yet complex ecologies of such regions.

Adapting from Vargona, (2013), community resilience may be defined as a community's ability, when it encounters or initiates major change, to achieve effective outcomes with minimal waste of resources. While a community is made up of resilient individuals it is positioned to quickly and effectively adapt to change. A collection of resilient people does not necessarily ensure that a community as a whole will be able to respond well to challenges in its environment - there is a certain element to the equation that also must be considered. People's own determination to get out of poverty should be matched by development agencies commitment to redistribute risk and build equality, thereby supporting them to thrive and prosper, rather than just cope and survive in a world of increasing risks. Resilience is seldom portrayed in the balance sheets or the annual reports of development agencies, but is even visible to the naked eye through the confidence that people portray and the narratives that they yield of hopefulness ways and means to support life full of zest. Certainly Nangi village has a resilient narrative and is able to convey a current life style that has quite features of ecological sustainability.

\section{Acknowledgments}

The current article draws partly from a research study previously undertaken by the first author with colleagues Sabin Jung Pandey and Dipak Poudel. The first author had the major responsibility of writing the original case study report on demand driven development. He along with his colleagues wishes to gratefully acknowledge the guidance offered by Professor Dr. Mahesh Banskota, faculty Dr. Dhiraj Giri, and the research field guide Mr. Kishor Rimal of the Kathmandu University and subsequent mentoring offered by Dr Venkat Pulla.

\section{REFERENCES}

Burnell, P. (2011). Foreign aid in a changing world. In V. Desai, \& R. B. Potter (Eds.), The companion to development studies ( $2^{\text {nd }}$ ed.). Chennai, India: Chennai Micro Print.

DCCEE. (2007). National climate change adaptation framework. Retrieved from

http://www.coag.gov.au/coag_meeting_outcomes/2007-04-13/doc s/national_climate_change_adaption_framework.pdf

Food and Agricultural Organisaiton, (2014). Retireved from http://www.fao.org/docrep/006/ad347e/ad347e01.htm

Hennessy, K., B. Fitzharris, B.C. Bates, N. Harvey, S.M. Howden, L. Hughes, J. Salinger and R. Warrick, (2007). Australia and New Zealand. Climate Change 2007: Impacts, Adaptation and Vulnerability. Contribution of Working Group II to the Fourth 
Assessment Report of the Intergovernmental Panel on Climate Change, M.L. Parry, O.F. Canziani, J.P. Palutikof, P.J. van der Linden and C.E. Hanson, Eds., Cambridge University Press, Cambridge, UK, 507-540.

Killick, T. (2011). Aid conditionality. In V. Desai, \& R. B. Potter (Eds), The Companion To Development Studies ( $2^{\text {nd }}$ ed.). Chennai, India: Chennai Micro Print.

Klein, R.J.T., S. Huq, F. Denton, T.E. Downing, R.G. Richels, J.B. Robinson, \& F.L. Toth. (2007). Inter-relationships between adaptation and mitigation of Climate Change 2007: Impacts, Adaptation and Vulnerability. Contribution of Working Group II to the Fourth Assessment Report of the Intergovernmental Panel on Climate Change, M.L. Parry, O.F. Canziani, J.P. Palutikof, P.J. van der Linden and C.E. Hanson, Eds., Cambridge University Press, Cambridge, UK, 745-777.

Ministry of Industry (MOI). (2010). Micro-Enterprises: Development for poverty alleviation. Kathmandu: MEDEP.

Park, N., Peterson, C., \& Seligman, M. (2004). Strengths of character and wellbeing. Journal of Social and Clinical Psychology, $23,603-619$

Parnewll, M. (2011). Agropolitan and bottom-up development. In V. Desai, \& R. B. Potter (Eds), The Companion To Development
Studies $\left(2^{\text {nd }}\right.$ ed.). Chennai, India: Chennai Micro Print.

Pun, M. (2007), Speech at Magassay Award Ceremony. Retrieved from

http://www.rmaf.org.ph/newrmaf/main/awardees/awardee/profile/ 145

Pulla, V. (2013). Coping and resilience: People's innovative solutions. International Journal of Innovation, Creativity and Change, 1 (1)

Pun, M. (2014). My early school days. Retrieved from http://www.himanchal.org/school-mahabir-pun.html

Sachs, J. (2005). The end of poverty: How can we make it happen in uur lifetime. New York: Penguin Books.

Sathu, A. (2008). I look back at the last 4 months and walk away smiling.. Retrieved from

http://anukoolinnepal.blogspot.com.au/2008/10/i-look-back-at-last -4-months-and-walk.html

United Nations Development Program (UNDP). (2011). Implementing the Paris Declaration on aid effectiveness. Kathmandu: UNDP.

Willis, K. (2005). Theories and practices of development. New York: Routledge 